\title{
ÜMINIS CHOLANGITAS: KLINIKINIS PASIREIŠKIMAS, DIAGNOSTIKA, GYDYMAS
}

\author{
Aurimas Reipšleger \\ Vilniaus universitetas, Medicinos fakultetas
}

\author{
Raktažodžiai: ūminis cholangitas, klinikinè išraiška, \\ diagnostika, gydymas, endoskopinè retrogradinè cholan- \\ giopankreatografija.
}

\begin{abstract}
Santrauka
Ūminis cholangitas yra gyvybei pavojinga būklè, reikalinga greitų ir efektyvių diagnostikos ir gydymo priemonių, siekiant išvengti tokių komplikacijų, kaip septinis šokas ir dauginis organų nepakankamumas. Ligai būdingas karščiavimas, dešiniojo viršutiniojo pilvo kvadranto skausmas, gelta. Auksinis diagnostikos standartas yra endoskopinè retrogradinè cholangiopankreatografija (ERCP), tačiau galima taikyti ir kitus vaizdinius tyrimus, leidžiančius vizualizuoti tulžies latakus. Dauguma pacientu pasveiksta taikant konservatyvius gydymo metodus, tačiau apie 15 proc. pacientų prireikia biliarinès dekompresijos, kuri dažniausiai atliekama taikant ERCP. Tyrimo tikslas - ịvertinti ir aptarti mokslinejje literatūroje pateikiamą informaciją apie ūminio cholangito klinikini pasireiškimą, diagnostiką bei gydymą.
\end{abstract}

\section{Ivadas}

Ūminis cholangitas yra gyvybei potencialiai pavojinga būklè, kurią charakterizuoja infekcija ir biliarinio medžio obstrukcija. Obstrukciją dažniausiai sukelia choledocholitiazè, gerybinè biliarinè stenozè, biliarinès anastomozès striktūra ir piktybinès ligos sukelta stenozè. Tulžies akmenys randami 10-15 proc. baltujų populiacijos Jungtinèse Amerikos Valstijose. Nemaža šių žmonių dalis patenka ị ligonines dèl biliarinès kolikos ir 6-9 proc. iš jų diagnozuojama ūmaus cholangito komplikacija [1]. Cholelitiazė anksčiau būdavo pati dažniausia obstrukcijos priežastis, bet piktybinès ligos, sklerozuojančo cholangito ir nechirurginių instrumentinių tyrimų sukelto cholangito paplitimas didèja [2]. Klasikinis cholangito klinikinis pasireiškimas, dar žinomas kaip Charcot triada, yra karščiavimas su šaltkèčiu, pilvo skausmas ir gelta. Reynold pentada, kurią sudaro Charcot triada kartu su hipotenzija ir sutrikusia sąmonès būkle, pasireiškia labai mažai daliai pacientų [3].

Tyrimo tikslas - išanalizuoti bei aptarti įrodymais pagrịstą informaciją apie ūminio cholangito klinikinị pasireiškimą, diagnostiką bei gydymą.

\section{Tyrimo medžiaga ir metodai}

Taikyta sisteminè mokslinès literatūros apžvalga ir analizè. Duomenų buvo ieškoma PubMed, Google Scholar, UpToDate bei Cochrane Libray duomenų bazėse. Viso teksto straipsniai atrinkti, jei jų pavadinimas, santrauka ar reikšminiai žodžiai nurodè, kad tyrimas tinkamas šiai apžvalgai. Naudoti raktažodžiai: acute cholangitis, clinical expression, diagnostics, treatment, endoscopic retrograde cholangiopancreatography.

\section{Tyrimo rezultatai}

Klinikinis pasireiškimas ir diagnostika. Cholangito išraiška priklauso nuo jo sunkumo. Klasikiniu atveju liga pasireiškia smarkiu karščiavimu, trunkančiu ilgiau nei 24 valandas, pilvo skausmu ir gelta - šis simptomų rinkinys vadinamas Charcot triada arba hepatiniu karščiavimu. Skausmas dažniausiai lokalizuojasi viršutiniame dešiniajame kvadrante ir yra vidutinio stiprumo. Kai ūmaus cholangito eiga tampa sunkesne, dar atsiranda hipotenzija ir sumišimas (Reynold pentada). Charcot triados mažas jautrumas $(26,4 \%)$, bet didelis specifiškumas $(95,9 \%)$. Charcot triada stebima nuo 26,4 iki 72 proc. pacientų, sergančių ūmiu cholangitu [3]. Iš pateiktų dažnių intervalų aiškiai matyti, kad vadinamoji klasikinè cholangito išraiška neretai nèra klasikinè. Dažnai gali nebūti vieno iš Charcot triadą sudarančių simptomų, bet galimas nerimo pojūtis ar net nekontroliuojamas drebejjimas [4].

Vaizdo tyrimai yra nepakeičiami diagnozuoti ūmini cholangitą. Dažniausi iš jų yra transabdominalinis ultragarsinis tyrimas, kompiuterinè tomografija, endoskopinè retrogradinè cholangiopankreatografija (ERCP), magnetinio rezonanso 
cholangiopankreatografija (MRCP) ir endoskopinè ultrasonografija (EUS). Transabdominalis ultragarsinis tyrimas yra greitas, jautrus ir specifiškas tulžies latakų išsiplètimą parodantis tyrimas, iprastai pirmiausiai pasirenkamas itarus ūminị cholangitą. Esant ankstyvai tulžies latakų obstrukcijai, kartais dar gali nebūti latakų dilatacijos, o choledocholitiazę transabdominalis ultragarsinis tyrimas parodo labai prastai. Kompiuterine tomografija yra daug jautresnis tyrimas diagnozuoti choledocholitiazę, nei transabdominalinis ultragarsinis tyrimas [5]. ERCP yra auksinis cholangito diagnozės standartas. Šio tyrimo metu galima pamatyti akmenų buvimą, stebèti obstrukcinius pažeidimus, stenozinius pakitimus ir netgi diagnozuoti cholangiokarcinomą. ERCP yra labai svarbus diagnostikai ir gydymui. MRCP pasižymi labai dideliu patikimumu, diagnozuojant cholangitą. Didelis MRCP privalumas, lyginant su ERCP, yra neinvazyvumas. MRCP metu galima ịvertinti intra- ir ekstrahepatinių latakų išsiplètimą, tulžies ir cholesterolio akmenis, mažo diametro striktūras. Atsižvelgiant ERCP invaziškumą ir galimas komplikacijas, MRCP igauna vis daugiau populiarumo [6].

Gydymas. Ūmaus cholangito pradiniam gydymui svarbūs šie aspektai: kristaloidų infuzija, parenteriniai empiriniu būdu parinkti antibiotikai (antibiotikai turi veikti žarnyno mikroflorą, nes iš ten kyla infekcija), nesteroidiniai vaistai nuo uždegimo, nulinè dieta per burną ir stebejimas dèl ịvairių pavojingų būklių, pavyzdžiui, septinio šoko. Prieš skiriant antibiotikus, reikètų paimti kraujo pasèli antibiotikų jautrumo patikslinimui. Trombozių profilaktikai galima mažomis dozėmis skirti spazmolitikų ir antikoaguliantų. Nepaprastai svarbu stebèti paciento būklès dinamiką. Pagal chirurginę literatūrą, $80-90$ proc. pacientų, esant vidutinio sunkumo cholangitui, gerai atsako ị konservatyvuji gydymą. Maždaug 15 proc. pacientų, nepaisant minèto gydymo, būklè blogèja ir jiems būtina kuo skubiau atlikti biliarinę dekompresiją [7]. Gydymo metodiką svarbu pasirinkti pagal ūmaus cholangito sunkumą. Sunkiu (dar vadinamas pūliuojančiu) üminis cholangitis laikomas, kai yra nors vienos organų sistemos nepakankamumas. Esant lengvam ar vidutinio lygio cholangitui, biliarinis drenažas turi būti atliktas per $24-48$ valandas. Kai paciento, sergančio lengva ar vidutinio lygio cholangito forma būklè nepaisant gydymo blogèja, arba esant sunkiam cholangitui, biliarine dekompresija turi būti atlikta per 24 valandas [7]. ERCP ir sfinkterotomija su akmens pašalinimu ir(ar) stento ịterpimu turètų būti pirmo pasirinkimo instrumentinè procedūra drenažui atlikti. Kartais ERCP techniškai neįmanoma atlikti, arba procedūra būna nesėkminga. Tokiais atvejais perkutaninè transhepatinè cholangiografija arba chirurgine dekompresija yra indikuotina. PTC kaip ir ERCP pasižymi puikia diagnostine verte ir leidžia atlikti tokias pačias terapeutines intervencijas. Atlikti PTC galima tik esant dilatuotai biliarinei sistemai ir ši procedūra laikoma invazyvesne, nei ERCP. Chirurginis drenažas taikomas pacientams, kuriems negalima atlikti arba nepasiteisino anksčiau minèti metodai, tačiau endoskopinis drenažas asocijuojamas su daug mažesniu mirštamumu ir sergamumu, lyginant su chirurgine dekompresija, atitinkamai $-4.7-10$ proc. ir $10-50$ procentu [8].

\section{Išvados}

1. Ūminiam cholangintui būdingas karščiavimas, viršutiniojo dešiniojo kvadranto pilvo skausmas bei gelta, tačiau ši simptomų kombinacija nèra didelio jautrumo.

2. Auksinis standartas diagnozuojant ūminị cholangitą yra ERCP, galima atlikti EUS, KT, MRCP.

3. $80-90$ proc. pacientu padeda konservatyvieji gydymo metodai. Apie 15 proc. pacientų reikia atlikti biliarinę dekompresiją. Pirmo pasirinkimo biliarinès dekompresijos metodas - ERCP.

\section{Literatūra}

1. Williams EJ, Green J, Beckingham I, Parks R, Martin D, Lombard M. Guidelines on the management of common bile duct stones (CBDS). Gut 2008;57(7):1004-21. https://doi.org/10.1136/gut.2007.121657

2. Kimura Y, Takada T, Kawarada Y, Nimura Y, Hirata K, Sekimoto $\mathrm{M}$, et al. Definitions, pathophysiology, and epidemiology of acute cholangitis and cholecystitis: Tokyo guidelines. J Hepatobiliary Pancreat Surg 2007;14(1):15-26.

https://doi.org/10.1007/s00534-006-1152-y

3. Ahmed M. Acute cholangitis - an update. World J Gastrointest Pathophysiol. 2018;9(1):1-7. https://doi.org/10.4291/wjgp.v9.i1.1

4. Kinney TP. Management of ascending cholangitis. Gastrointest Endosc Clin N Am 2007;17(2):289-306, vi. https://doi.org/10.1016/j.giec.2007.03.006

5. Gallix BP, Aufort S, Pierredon MA, Garibaldi F, Bruel JM. Acute cholangitis: imaging diagnosis and management. J Radiol 2006;87(4 Pt 2):430-40.

https://doi.org/10.1016/S0221-0363(06)74025-2

6. Mohammad Alizadeh AH. Cholangitis: diagnosis, treatment and prognosis. J Clin Transl Hepatol 2017;5(4):404-13.

https://doi.org/10.14218/JCTH.2017.00028

7. Acute Cholangitis Treatment \& Management: Prehospital Care, Emergency Department Care, Medical Care. 2021. https:// emedicine.medscape.com/article/774245-treatment

8. Lai EC, Mok FP, Tan ES, Lo CM, Fan ST, You KT, et al. Endoscopic biliary drainage for severe acute cholangitis. N Engl J Med 1992;326(24):1582-6.

https://doi.org/10.1056/NEJM199206113262401 


\section{4}

\section{ACUTE CHOLANGITIS: CLINICAL EXPRESSION, DIAGNOSTICS, TREATMENT}

\section{A. Reipšleger}

Keywords: acute cholangitis, clinical expression, diagnostics, treatment, endoscopic retrograde cholangiopancreatography.

Summary

Acute cholangitis is a life-threatening condition that necessitates atimely diagnosis and treatment in order to prevent the development of severe complications, such as sepsis and multiple organ failure. Patients typically present with fever, right upper abdominal quadrant pain and jaundice. Endoscopic retrograde cholangiopancreatography is the diagnostic method of choice for acute cholangitis; however, all imaging methods that allow for the visualisation of the biliary tract may aid in diagnosing this condition. The majority of patients respond well to conservative treatment. Up to $15 \%$ of patients require biliary decompression, which is best achieved by ERCP.
Conclusions: 1. A combination of fever, right upper abdominal quadrant pain and jaundice is highly specific of acute cholangitis, though the sensitivity is low. 2. ERCP is the diagnostic method of choice in diagnosing acute cholangitis. Other imaging methods, such as endoscopic ultrasound, computerised tomography and magnetic resonance cholangiopancreatography may also aid in diagnosing the condition. 3. $80-90 \%$ of patients get better with conservative treatment. Up to $15 \%$ of patients require biliary decompression by ERCP.

Correspondence to: aurimas.reipsleger@gmail.com

Gauta 2021-05-02 